\title{
IMPLEMENTASI KEBIJAKAN PENGELOLAAN TATA RUANG WILAYAH KONSERVASI DAN PARIWISATA
}

\section{MANAGEMENT POLICY IMPLEMENTATION OF SPATIAL REGION CONSERVATION AND TOURISM}

\author{
Arinda Novpika Nerustia ${ }^{1}$, Rita Rahmawati ${ }^{2}$, Denny Hernawan ${ }^{3}$. \\ ${ }^{1}$ Jurusan Ilmu Administrasi Negara Fakultas Ilmu Sosial dan Ilmu Politik Universitas Djuanda, Jl. Tol \\ Ciawi No. 1, Kotak Pos 35 Bogor 16770 \\ 2Jurusan Ilmu Administrasi Negara Fakultas Ilmu Sosial dan Ilmu Politik Universitas Djuanda, Jl. Tol \\ Ciawi No. 1, Kotak Pos 35 Bogor 16770 \\ ${ }^{3}$ Jurusan Ilmu Administrasi Negara Fakultas Ilmu Sosial dan Ilmu Politik Universitas Djuanda, Jl. Tol \\ Ciawi No. 1, Kotak Pos 35 Bogor 16770 \\ ${ }^{a}$ Korespondensi: Arinda Novpika.
}

(Diterima oleh Dewan Redaksi: 01-02-2015)

(Dipublikasikan oleh Dewan Redaksi: 01-05-2015 )

\begin{abstract}
Puncak region Bogor as buffer capital Jakarta was being problem that was not easily resolved by all the competent authorities. Factor of natural damage caused by use of conservation land in an uncontrolled made the field and land space in the area threatens the abrasion of land surrounding hills. Puncak region Bogor was a part of an exclusive area that had room in its utilization. One of them was about the expansion of settlements to get the occupancy requirement level. However, this pattern should be observed not as the freedom to utilize space in the region, but the construction was systematically measured and targeted so as not to alter the pattern of the region of space become corrupted and no longer serves as a buffer area around it.

Edward III stated that to measure the success of a policy implementation could be measured through the four basic variables of the communication; sources: disposition or attitude of the executive and bureaucratic structure.

Implementation of spatial management policies in the Cisarua district referred to the existing regulations. This research examined two sources of policy implementation in Cisarua district in which Presidential Regulation Number 54, 2008 on National Strategic Planning Region Jakarta, Bogor, Depok, Tangerang, Jakarta, Puncak, Cianjur (Jabodetabekpuncur), and Regulation of Bogor District No. 19 of 2008 Concerning the Spatial Plan Bogor regency 20052025. Misuse of land, because its permit was easy from Buildings Licensing Agency, but supervision was not done from the agency concerned. This, which was perceived by the technical implementation in the field, which lack the resources and authority possessed limited.

From this research was concluded that the element of implementing the policy and resources were still relatively minimal.
\end{abstract}

\section{ABSTRAK}

Kawasan Puncak Bogor sebagai penyangga Ibu Kota Jakarta, menjadi beban masalah yang tidak mudah terejawantahkan oleh semua pihak yang berkompeten. Faktor kerusakan alam akibat penggunaan lahan konservasi secara tidak terkendali membuat bidang dan ruang lahan di daerah tersebut mengancam terjadinya abrasi lahan perbukitan di sekitarnya. Kawasaan Puncak Bogor adalah bagian dari sebuah daerah yang memiliki ruang ekslusif dalam pemanfaatannya. 
Salah satu didalammnya soal perluasan pemukiman untuk memenuhi tingkat kebutuhan hunian. Namun pola ini harus dapat dicermati bukan sebagai kebebasan untuk mempergunakan ruang di kawasan tersebut, melainkan melakukan pembangunan yang terukur dan terarah secara sistematis sehingga tidak merubah pola ruang kawasan menjadi rusak dan tidak lagi berfungsi sebagai penyangga daerah disekitarnya.

Edward III menyebutkan bahwa untuk mengukur keberhasilan suatu implementasi kebijakan dapat diukur melalui empat variabel dasar yaitu komunikasi; sumber-sumber; disposisi atau sikap para pelaksana serta struktur birokrasi. Metode penelitian menggunakan studi kasus serta tingkat eksplanasi secara deskriptif.

Implementasi kebijakan pengelolaan tata ruang di kecamatan Cisarua mengacu pada regulasi yang ada, penelitian ini mengkaji dua sumber kebijakan dalam pelaksanaannya di kecamatan Cisarua yaitu Peraturan Presiden Nomor 54 Tahun 2008 Tentang Penataan Kawasan Strategis Nasional Jakarta, Bogor, Depok, Tangerang, Bekasi, Puncak,Cianjur (Jabodetabekpuncur) dan Peraturan Daerah Kabupaten Bogor Nomor 19 tahun 2008 Mengenai Rencana Tata Ruang Wilayah kabupaten Bogor Tahun 2005-2025. Terjadi penyalahgunaan lahan, karena perizinan yang mudah dari Badan Perizinan Bangunan, namun pengawasan tidak dilakukan dari instansi yang bersangkutan. Hal ini, yang dirasakan oleh para pelaksana teknis dilapangan, sumber daya yang masih kurang serta kewenangan yang dimiliki terbatas.

Dari penelitian ini disimpulkan bahwa unsur pelaksana kebijakan beserta sumber-sumber masih relatif minim. Sehingga perlu dilakukannya peningkatan sumber-sumber tersebut guna meningkatkan pengawasan dalam kasus tata ruang-kawasan Puncak kecamatan Cisarua.

Kata kunci : tata ruang, impelementasi, kebijakan

Arindra Novpika, 2015. Implementasi Kebijakan Pengelolaan Tata Ruang Wilayah Konservasi dan Pariwisata. Jurnal Governansi.

\section{PENDAHULUAN}

Semakin tingginya kebutuhan hunian pada saat ini, memaksa terjadinya degradasi lahan di beberapa tempat yang semestinya menjadi zona aman untuk sejumlah kawasan. Secara perlahan, penggunaan lahan yang berada di beberapa daerah kawasan tersebut membentuk karakter yang tidak ramah lingkungan bahkan berpotensi menyebabkan bencana nasional. Biasanya, kawasan zona aman ini tidak pada satu wilayah administrasi melainkan terbagi ke beberapa wilayah administrasi pemerintahan yang berbeda. Perbedaan kewenangan dan kebijakan, mengakibatkan pengelolaan lahan menjadi tidak jelas hingga mengancam kawasan zona aman tersebut berubah fungsi dari asalnya.

Pengembangan pembangunan yang menyita berbagai bidang lahan dan ruang, mengikis peran alam sebagai pelindung menjadi bumerang bagi daerah-daerah tersebut tidak terkecuali daerah yang berada di muara kawasan zona aman tersebut. Awalnya persoalan ini seperti tidak tampak serius, namun dalam kurun waktu tertentu, masalah pengelolaan lahan yang menyimpang dikawasan zona aman, menjadi masalah "gunung es" yang sulit dipecahkan.

Penataan ruang yang mengatur berbagai kepentingan lintas sektor maupun lintas wilayah, memiliki peran strategis dalam upaya pelestarian kawasan konservasi. Penataan ruang berupaya menjaga keseimbangan agar fungsi dan pemanfaatan ruang konservasi dapat dioptimalkan secara berkelanjutan. Namun saat ini, sebagian besar kawasan konservasi mengalami degradasi baik fungsi maupun kuantitasnya. Selain karena faktor alam juga disebabkan oleh perubahan fungsi dan ulah manusia. Masyarakat masih memiliki tingkat 
ketergantungan yang tinggi terhadap sumber daya alam yang ada di kawasan konservasi. Sebagian masyarakat memenuhi berbagai kebutuhan hidup seperti pangan, sandang, dan bahan bangunan seringkali masih mengambil dari dalam kawasan konservasi. Selain itu, adanya konflik nyata dari berbagai sektor seperti kehutanan dan perkebunan menjadi salah satu faktor penyebab degradasi. Diperlukan adanya kebijakan Pemerintah untuk memaduserasikan sektor kehutanan, pertambangan, dan perkebunan.

Kondisi seperti tadi, jelas sangat begitu tampak di Kawasan Puncak Bogor. Daerah yang disebut sebagai penyangga Ibu Kota Jakarta, menjadi beban masalah yang tidak mudah terejawantahkan oleh semua pihak yang berkompeten. Faktor kerusakan alam akibat penggunaan lahan konservasi secara tidak terkendali membuat bidang dan ruang lahan di daerah tersebut berubah menjadi "gunung pemukiman" yang mengancam abrasinya lahan perbukitan di sekitarnya. Bahwa Kawasaan Puncak Bogor adalah bagian dari sebuah daerah yang memiliki ruang ekslusif dalam pemanfaatannya. Salah satu didalammnya soal perluasan pemukiman untuk memenuhi tingkat kebutuhan hunian. Namun pola ini harus dapat dicermati bukan sebagai kebebasan untuk mempergunakan ruang di kawasan tersebut untuk kepentingan tadi, melainkan melakukan pembangunan yang terukur dan terarah secara sistematis sehingga tidak merubuah pola ruang kawasan menjadi rusak dan tidak lagi berfungsi sebagai penyangga daerah disekitarnya.

Kawasan Puncak Bogor dalam persfektif Tata Ruang adalah kawasan atau lingkungan yang memiliki nilai penting untuk membangun kawasan hijau penyangga kota Jakarta. Sehingga secara terukur, pengawasan terhadap pemanfaatan ruang di kawasan puncak untuk sejumlah kepentingan sangat ketat dilakukan. Dalam prespektif tata ruang, Puncak Bogor jelas telah dibentuk sebagai kawasan yang ditujukan sebagai kawasan lindung. Sehingga secara efektif diharapkan dapat menjadi penyeimbang laju pembangunan kawasan Jabodetabek dalam beragam hal. Salah satunya sebagai pemasok oksigen bagi penduduk ibu kota.

Secara terpadu puncak akhirnya menempatkan diri sebagai tempat kunjungan wisata dengan sejumlah keeksotikan panorama alammnya. Namun berbagai masalah masih menyelimuti wilayah Puncak Bogor ini. Satu di antara masalah itu yakni adanya gelar yang disandangnya, seakan merupakan kontributor banjir terbesar bagi Jakarta karena pelanggaran peruntukan lahan setempat.

Puncak Bogor sebagai kawasan pariwisata yang juga memiliki fungsi ganda yaitu sebagai kawasan resapan air, sepertinya di salah artikan oleh banyak pihak terutama pemerintah daerah, karena perkembangan pembangunan yang nampak disepanjang jalan raya puncak dan sekitarnya, tidak mencerminkan bahwa pemerintah daerah memiliki arah kebijakan yang jelas dalam melakukan tata ruang di kawasan Puncak Bogor.

Perhatian Pemerintah Pusat terhadap peran dan fungsi Kawasan Puncak sudah ada sejak diterbitkannya Keputusan Presiden RI No. 3 Tahun 1963 Tentang Penertiban Pembangunan Baru Sepanjang Jalan antara Jakarta - Bogor - Cianjur. Sejak saat itu, antisipasi terhadap perkembangan wilayah ini sudah menjadi perhatian karena keberadaan Puncak sangat strategis, baik dari segi keindahan alam, dan iklimnya yang sejuk serta merupakan perlintasan regional yang menghubungkan wilayah Barat Jawa Barat ( Bandung - Jakarta ). Sebenarnya Kepres tersebut dapat menjadi pedoman dalam menyikapi dan membuat kebijakan-kebijakan pembangunan kawasan Bopuncur sehingga ada kesinambungan kebijakan antara pemerintah pusat dan daerah.

Selanjutnya kebijakan tentang kawasan Puncak diperkuat dengan dikeluarkannya Peraturan Pemerintah (PP) No.47 Tahun 1997 tentang Rencana Tata Ruang Wilayah Nasional. Dalam peraturan tersebut Kawasan Bopuncur (Bogor, Puncak, Cianjur) dikategorikan sebagai kawasan tertentu yang memerlukan penanganan khusus dan merupakan kawasan bernilai strategis, yakni 
sebagai kawasan yang memberikan perlindungan wilayah yang berada dibawahnya, Daerah Provinsi Jawa Barat dan DKI Jakarta. Komitmen nasional tersebut di atas faktanya tidak dipatuhi oleh berbagai pihak yang diduga memiliki kepentingan ekonomis tertentu. Bentuk pelanggaran tersebut di antaranya penyalahgunaan peruntukan lahan, dari status konservasi menjadi kawasan permukiman.

Begitu kompleksnya permasalahan Puncak ini hingga kemudian dikeluarkan regulasi baru berupa Peraturan Presiden (yang selanjutnya disebut Perpres) Nomor 54 Tahun 2008 Tentang Penataan Kawasan Jakarta, Bogor, Depok, Tangerang, Bekasi, Puncak dan Cianjur untuk mengelola kembali kawasan sentral yang semrawut. Pada tahun yang sama Pemerintah Daerah Kabupaten Bogor mengeluarkan Peraturan Daerah (yang selanjutnya disebut Perda) Nomor 19 Tahun 2008 Tentang Rencana Tata Ruang Wilayah Kabupaten Bogor 2005-2025.

Ketidak sesuaian antara pemanfaatan lahan, baik pada kawasan budidaya dan kawasan lindung, terhadap kondisi fisik di lapangan menyebabkan terjadinya penyimpangan peruntukan lahan yang berujung kepada menurunnya fungsi lahan tersebut. Menurunnya fungsi lahan dari segi ekologis sering berdampak negatif yaitu terjadinya kerusakan lingkungan seperti erosi, banjir, tanah longsor, dan sebagainya. Tidak sedikit villa-villa bertebaran tanpa aturan dan hampir disetiap desa di Kecamatan Cisarua. Bangunan-bangunan yang berdiri kokoh tersebut, sepertinya mudah dalam mempeoleh perizinannya. Pemerintah daerah sudah barang tentu memiliki tanggung jawab untuk melakukan penataan kembali kawasan Puncak yang sudah sangat semerawut. Dinas Tata ruang dan Pertanahan Kabupaten Bogor selayaknya turut andil dalam pembenahan ini. Namun permasalahannya sudah begitu komplek, dimulai dari silih bergantinya regulasi yang memayungi masalah ini, kemudian kewenangan yang diberikan pusat ke pada pemerintah daerah masih kurang, ditambah lagi kurangnya pengawasan terhadap penataan tata ruang tersebut yang disebabkan kuranngya aparat pelaksana dilapangan (Kompas.com,edisi 23 Maret 2011).

Salah satunya, ada beberapa kasus yang mencuat baik dimedia cetak maupun elektronik dan pembicaraan masalah sekitar, seperti kasus Penyegelan Taman Wisata Matahari, kemudian Kasus kerusuhan Yayasan BPK Penabur adapula penertiban dan pembongkaran bangunan semi permanen.

Berdasarkan latar belakang yang telah dikemukakan, sehingga penelitian mengambil judul " Implementasi Kebijakan Pengelolaan Tata Ruang Wilayah Konservasi dan Pariwisata (Studi Kasus Kawasan Puncak Kecamatan Cisarua Kabupaten Bogor) “.

\section{MATERI DAN METODE}

Mulai Pendekatan yang digunakan dalam penelitian ini adalah pendekatan kualitatif, dimana menggunakan sampel sederhana dengan tingkat eksplanasinya secara deskriptif karena dalam hal ini peneliti mencoba mengemukakan maupun menjelaskan temuan dilapangan serta dilakukan untuk mengetahui nilai mandiri, baik satu variabel atau lebih (independen) tanpa membuat perbandingan atau menghubungkan antara variabel satu dengan variabel lain untuk jenis penelitian kualitatif seperti judul berikut Implementasi Kebijakan Pengelolaan Tata Ruang Wilayah Konservasi dan Pariwisata dengan studi kasus Kawasan Puncak Kecamatan Cisarua Kabupaten Bogor menggunakan pula pendekatan studi kasus guna mempelajari secara intensif tentang latar belakang keadaan sekarang da interaksi lingkungan unit sosial, individu, kelompok, lembaga atau masyarakat (Cholid Narbuko, 2004:46).

\subsection{Fokus Penelitian}

Menurut Edward III salah satu pendekatan studi implementasi adalah harus dimulai dengan pernyataan abstrak, seperti yang dikemukakan sebagai berikut, yaitu :

1. Apakah yang menjadi prasyarat bagi implementasi kebijakan? 
2. Apakah yang menjadi faktor penghambat utama bagi keberhasilan implementasi kebijakan?

Sehingga untuk menjawab pertanyaan tersebut di atas, Edward III, mengusulkan 4 (empat) variabel yang sangat mempengaruhi keberhasilan implementasi kebijakan, yaitu :

\section{Communication (komunikasi) ;} komunikasi merupakan sarana untuk menyebarluaskan informasi, baik dari atas ke bawah maupun dari bawah ke atas. Untuk menghindari terjadinya distorsi informasi yang disampaikan atasan ke bawahan, perlu adanya ketetapan waktu dalam penyampaian informasi, harus jelas informasi yang disampaikan, serta memerlukan ketelitian dan konsistensi dalam menyampaikan informasi .

2. Resourcess (sumber-sumber) ; sumbersumber dalam implementasi kebijakan memegang peranan penting, karena implementasi kebijakan tidak akan efektif bilamana sumber-sumber pendukungnya tidak tersedia. Yang termasuk sumbersumber dimaksud adalah :

a. Staf yang relatif cukup jumlahnya dan mempunyai keahlian dan keterampilan untuk melaksanakan kebijakan

b. Informasi yang memadai atau relevan untuk keperluan implementasi.

c. Dukungan dari lingkungan untuk mensukseskan implementasi kebijakan

d. Kewenang yang dimiliki implementor untuk melaksanakan kebijakan.

3. Dispotition or Attitude (sikap) ; berkaitan dengan bagaimana sikap implementor dalam mendukung suatu implementasi kebijakan. Seringkali para implementor bersedia untuk mengambil insiatif dalam rangka mencapai kebijakan, tergantung dengan sejauh mana wewenang yang dimilikinya

4. Bureaucratic structure (struktur birokrasi); suatu kebijakan seringkali melibatkan beberapa lembaga atau organisasi dalam proses implementasinya, sehingga diperlukan koordinasi yang efektif antar lembaga-lembaga terkait dalam mendukung keberhasilan implementasi.

\section{Gambar 3.1 \\ Model Implementasi Kebijakan Publik Menurut Edward III}

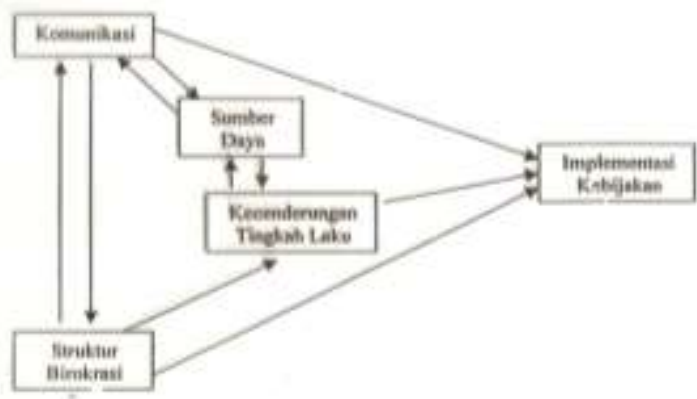

Sumber: Edward III dalam Leo Agustino (2008:150)

\section{Jenis dan Teknik Pengumpulan Data.}

Dalam melaksanakan penelitian ini terdapat tahap - tahap yang dilakukan untuk mendapatkan data secara lengkap dengan menggali informasi, adalah sebagai berikut :

1. Studi Kepustakaan

Teknik ini dilakukan dengan mempelajari berbagai literatur yang berkaitan dengan masalah yang diteliti, khususnya mengenai kebijakan dan tata ruang.

2. Studi Lapangan

Teknik ini merupakan inti dari dilakukannya penelitian dimana peneliti melakukan peninjauan langsung kelapangan atau lokasi penelitian untuk menemukan masalah dan diungkapkan secara lengkap.

Dalam penelitian ini terdapat 2 jenis data yang dapat dijadikan sumber untuk mendukung pengumpulan data, antara lain :

1. Sumber Data Primer

Adalah sumber data yang diperoleh langsung dari dengan narasumber atau informan yang terkait dengan masalah yang hendak diteliti. Antara lain:

a. Teknik Wawancara

Adalah suatu usaha memperoleh data secara langsung dengan mengadakan wawancara dengan pihak yang berwenang dalam perusahaan tentang hal-hal yang berhubungan dengan masalah yang diteliti. Menurut Suharsimi Arikunto (2002:202) Secara 
garis besar ada dua macam pedoman wawancara:

1) Pedoman wawancara tidak terstruktur, yaitu pedoman wawancara hanya menurut garis besar yang akan ditanyakan. Tentu saja kreativitas pewawancara sangat diperlukan, bahkan hasil wawancara dengan jenis pedoman ini lebih banyak tergantung dari pewawancara. Pewawancaralah sebagai pengemudi jawaban responden. Jenis interviu ini cocok untuk penelitian kasus.

2) Pedoman wawancara terstruktur, yaitu pedoman wawancara yang disusun secara terperinci sehingga menyerupai check-list.

Pewawancara tinggal membubuhkan tanda $v$ (check) pada nomor yang sesuai.

Maksud mengadakan wawancara, seperti ditegaskan oleh Lincoln dan Guba (1985:266) dalam Lexy J. Moleong (2001:135), antara lain: mengkontruksi mengenai orang, kejadian, kegiatan, organisasi, perasaan, motivasi, tuntutan, kepedulian dan lain-lain kebulatan; merekontruksi kebulatan-kebulatan sebagai yang dialami masa lalu; memproyeksikan kebulatan-kebulatan sebagai yang telah diharapkan untuk dialami pada masa yang akan dating; memverifikasi, mengubah dan memperluas informasi yang diperolehcdari orang lain, baik manusia maupun bukan manusia (triangulasi); dan memverifikasi, mengubah dan memperluas konstruksi yang dikembangkan oleh peneliti sebagai pengecekan anggota.

Wawancara dilakukan terhadap narasumber yang berkaitan langsung dengan kajian penelitian adalah pelaksana kebijakan seperti camat dan kepala seksi yang berada dalam struktur Kecamatan Cisarua.

b. Observasi

Adalah teknik memperoleh data dengan cara meneliti dan mengamati secara langsung pada sumber data yang akan dianalisis mengenai analisis pengorganisasian yang diteliti. Observasi bukan hanya mencatat tetapi juga mengadakan pertimbangan kemudian mengadakan penilaian terhadap suatu skala bertingkat.

\section{Sumber Data Sekunder}

Adalah sumber data yang diperoleh dari narasumber berupa data-data yang sudah tersedia misalnya dengan cara membaca, melihat atau mendengarkan, misalnya:

\section{a. Dokumenter}

Teknik ini dilakukan dengan mengadakan penelitian serta mempelajari data berupa naskah, brosur, laporan-laporan, foto, surat, buu, dokumen, catatan dan lain-lain yang memiliki relevansi dengan penelitian.

Kemudian data-data yang diperoleh dari studi kepustakaan dijadikan perbandingan dengan data yang diperoleh dari studi lapangan. Diharapkan dalam penelitian ini diperoleh data yang seakurat mungkin guna pemaparan hasil penelitian secara lengkap dan jelas sesuai realita dilapangan.

\section{Pengolahan dan Analisis Data.}

Setelah data terkumpul dari hasil pengumpulan data langkah yang ditempuh adalah melakukan analisis data. Pada bagian analisis data diuraikan proses pelacakan dan pengaturan secara sistematis transkip-transkip wawancara, catatan lapangan dan bahanbahan lain agar peneliti dapat menyajikan temuannya. Analisis ini melibatkan pengerjaan, pengorganisasian, pemecahan dan sintesis data serta pencarian pola, pengungkapan hal penting dan penentuan apa yang akan dilaporkan. Dalam penelitian kualitatif, analisis data dilakukan selama dan setelah pengumpulan data. Langkah-langkah analisis data adalah sebagai berikut:

\section{a. Pengumpulan Data}

Pada tahap ini, peneliti dapat memulai proses klasifikasi awal (secara umum). Pada proses ini pula idealnya seorang peneliti juga melakukan pelacakan, pencatatan, pengorganisasian data yang relevan untuk memfokuskan pada masalah yang diteliti.

\section{b. Reduksi Data (Data Reduction)}

Data yang diperoleh cukup banyak, untuk itu 
diperlukan pencatatan secara teliti dan rinci. Seperti telah dikemukakan, semakin lama peneliti terjun ke lokasi penelitian, maka jumlah data akan semakin banyak, kompleks dan rumit serta bervariasi. Untuk itu perlu segera dilakukan analisis data melalui reduksi data. Mereduksi data berarti merangkum, memilih hal-hal pokok, memfokuskan pada hal-hal penting, dicari tema dan polanya. Dengan demikian data yang telah direduksi akan memberikan penggambaran lebih jelas dan mempermudah peneliti untuk melakukan pengumpulan data tahap berikutnya serta mencarinya bila diperlukan.

c. Penyajian Data (Daya Display)

Setelah data direduksi, maka langkah selanjutnya adalah mendisplaykan data. Dalam penelitian kualitatif, penyajian data dapat dilakukan dalam bentuk uraian singkat, bagan, hubugan antar kategori, flowchart dan sejenisnya. Data yang diperoleh tersebut bisa disajikan dalam bentuk matrik maupun tabel-tabel yang bisa mewakili karakter yang diperlukan.

\section{d. Penafsiran Data (Verification)}

Membuat kesimpulan sementara dan menguji kembali dengan metode triangulasi, baik menggunakan triangulasi peneliti, teori, data, maupun metode. Dan tahap terakhir, yaitu membuat pernyataan atau simpulan mengenai apa yang dimengerti secara utuh tentang suatu masalah setelah diteliti dalam bahasa kualitatif secara deskriptif dan bersifat interpretatif.

\section{Teknik Keabsahan Data}

Bagian ini memuat uraian tentang usaha-usaha peneliti memperoleh keabsahan temuannya. Agar diperoleh temuan dan interpretasi data yang absah, perlu diteliti kredibilitasnya dengan menggunakan teknikteknik perpanjangan kehadiran peneliti di lapangan, observasi diperdalam, triagulasi (menggunakan beberapa sumber, metode, peneliti dan teori), pembahasan sejawat, analisa kasus negative, pelacakan kesesuaian hasil dan pengecekan anggota. Selanjutnya perlu dilakukan pengecekan dapat atau tidaknya ditransfer ke latar lain (transferability), ketergantungan pada konteksnya (dependability) dan dapat atau tidaknya dikonfirmasikan kepada sumbernya (comfirmability) (Sylvia Saraswati, 2009:73).

\section{HASIL DAN PEMBAHASAN}

\section{Kondisi Geografis}

Kecamatan Cisarua merupakan salah satu dari 40 Kecamatan yang ada di Kabupaten Bogor Provinsi Jawa Barat dengan luas wilayah 6.373,62 Ha. Ketinggian dari permukaan laut $650 \mathrm{M}-1400 \mathrm{M}$ dengan letak geografis $06^{0} 42^{\prime}$ LS- $106^{0} 56^{\prime} \mathrm{BB}$. Memiliki suhu maksimum $23,91^{\circ} \mathrm{C} / 17,17,85^{\circ} \mathrm{C}$, banyaknya curah hujan $3178 \mathrm{~mm} / \mathrm{t}$ dan jumlah hari dengan curah hujan yang terbanyak adalah 40 hari. Bentuk wilayah $35 \%$ dataran, $40 \%$ perbukitan dan $25 \%$ pegunungan.

Batas administratif wilayah Kecamatan Cisarua antara lain :

a. Sebelah Utara berbatasan dengan

Kecamatan Sukaraja dan Kecamatan Babakan Madang

b. Sebelah Selatan berbatasan dengan : Gunung Pangrango

c. Sebelah Timur berbatasan dengan Kabupaten Cianjur

d. Sebelah Barat berbatasan dengan Kecamatan Megamendung

Jarak pusat pemerintahan kecamatan dengan:

a. Desa/Kelurahan terjauh

b. Ibukota Kabupaten Bogor : $40 \mathrm{Km}$

c. Ibukota Provinsi Jawa Barat $\quad: 100 \mathrm{Km}$

d. Ibukota Negara RI Jakarta : $80 \mathrm{Km}$

\section{Kondisi Demografis}

Kecamatan Cisarua Terdiri dari 9 (sembilan) Desa dan 1 (satu) Kelurahan, 38 Dusun, 73 Rukun Warga (RW) serta 260 Rukun Tetangga (RT) dengan jumlah penduduk perbulan sebanyak 113.710 jiwa dengan 31.137 Kepala Keluarga (KK). Jumlah penduduk berdasarkan jenis kelamin antara lain: Laki-Laki berjumlah 58.417 orang dan perempuan 55.293 orang.

Tabel

Daftar Desa/Kelurahan di Kecamatan Cisarua 


\begin{tabular}{clcc}
\hline No & $\begin{array}{c}\text { Nama } \\
\text { Desa/Kelurahan }\end{array}$ & $\begin{array}{c}\text { Luas } \\
\text { Wilayah } \\
(\mathrm{Ha})\end{array}$ & $\begin{array}{c}\text { Luas } \\
\text { Wilayah } \\
\left(\mathrm{Km}^{2}\right)\end{array}$ \\
\hline 1 & Kelurahan Cisarua & 200 & 2.000 \\
2 & Desa Tugu Selatan & 712,16 & $2.120,16$ \\
3 & Desa Tugu Utara & 1703 & 17.030 \\
4 & Desa Batulayang & 226 & 2.260 \\
5 & Desa Cibeureum & 1128,62 & $11.280,6$ \\
& & & 2 \\
6 & Desa Citeko & 462 & 4.620 \\
7 & Desa Kopo & 453,21 & $4.530,21$ \\
8 & Desa & 135,18 & $1.350,18$ \\
& Leuwimalang & & \\
9 & Desa Jogjogan & 154 & 1.540 \\
10 & Desa Cilember & 200 & 2.000 \\
\hline
\end{tabular}

Sumber: Data Monografi Kecamatan Cisarua 2010

\section{Kondisi Sosial Ekonomi}

Melihat dari kondisi geografis, Kecamatan Cisarua merupakan wilayah yang besaran perbukitannya lebih besar sehingga masih terbilang kawasan hijau, dimana masyarakatnya mayoritas memiliki mata pencaharian sebagai petani. Seperti dalam tabel berikut :

\section{Tabel}

Data Penduduk Menurut Mata Pencaharian

\begin{tabular}{|c|l|c|}
\hline No & Jenis Mata Pencaharian & $\begin{array}{c}\text { Jumlah } \\
\text { (orang) }\end{array}$ \\
\hline 1 & Petani & 12.431 \\
& - Petani pemilik tanah & 843 \\
& - Petani penggarap tanah & 6.115 \\
& - Buruh Tani & 5.477 \\
\hline 2 & Nelayan & - \\
\hline 3 & Pengusaha & - \\
\hline 4 & Pengrajin & 389 \\
\hline 5 & Industri Kecil & - \\
\hline 6 & Buruh Industri & 290 \\
\hline 7 & Pertukangan & 1.127 \\
\hline 8 & Buruh Pertambangan & - \\
\hline 9 & Buruh Perkebunan & 2.258 \\
\hline 10 & Pedagang & 5.782 \\
\hline 11 & Pengemudi/Jasa & 1.138 \\
\hline 12 & Pegawai Negeri Sipil & 573 \\
\hline 13 & TNI/POLRI & 91 \\
\hline 14 & Pensiunan/Purnawirawan & 288 \\
\hline 15 & Lain-lain & - \\
\hline \multicolumn{2}{|c|}{ Sumber: Data Monografi } & Kecamatan \\
Cisarua 2010 & \\
\hline
\end{tabular}

\subsubsection{Organisasi Pemerintahan Kecamatan Cisarua}

Tugas Kecamatan adalah membantu Bupati dalam menyelenggarakan pemerintahan, pembangunan dan pembinaan kehidupan kemasyarakatan serta melaksanakan sebagian kewenangan Bupati berdasarkan pelimpahan wewenang dengan fungsi:

a. Penyelenggaraan tugas-tugas kecamatan dan pembinaan desa/kelurahan

b. Penyelenggaraan tugas-tugas ketentraman dan ketertiban umum

c. Pengkoordinasian pembangunan dan kemasyarakatan

d. Penyelenggaraan pelayanan umum

e. Pengkoordinasian perangkat daerah dalam wilayah kerja kecamatan

f. Pelaksanaan partisipasi masyarakat dalam pemerintahan, pembangunan dan kemasyarakatan.

Berdasarkan Peraturan daerah Kabupaten Bogor Nomor 24 Tahun 2008 tentang Organisasi dan Tata Kerja Kecamatan. Kecamatan merupakan unsur pelaksana kewilayahan pada tingkat kecamatan dalam penyelenggaraan pemerintah daerah, dipimpin oleh seorrang camat yang berkedudukan dibawah dan bertanggung jawab kepada Bupati melalui Sekretaris Daerah.

Berdasarkan keputusan Bupati Nomor 138/575/Kpts/Huk/2008 tanggal 19 Desember 2008 tentang Penetapan Kecamatan Pola Maksimal dan Minimal, Kecamatan Cisarua termasuk dalam kategori pola maksimal, yang terdiri dari:

a. Camat

b. Sekretaris Kecamatan, yang membawahi:

- Subag Program dan Evaluasi

- Subag Keuangan

- Subag Umum dan Kepegawaian

c. Seksi Pemerintahan;

d. Seksi Perekonomian;

e. Seksi Pembangunan;

f. Seksi Ketentraman dan Ketertiban Umum;

g. Seksi Kesejahteraan Rakyat.

Kelima seksi tersebut dijabat oleh Kepala Seksi yang mencerminkan prinsip bagi habis tugas dan spesifikasi jabatan serta tanggung jawab yang harus diemban oleh masing- 
masing kepala seksi. Sedangkan dilingkungan sekretariat dipimpin oleh seorang Sekretaris (Struktur Organisasi terlampir).

Kecamatan Cisarua mempunyai tugas membantu Bupati dalam menyelenggarakan pemerintahan, pembangunan dan pembinaan kemasyarakatan serta melaksanakan sebagian kewenangan Bupati berdasarkan pelimpahan kewenangan.

Dalam menyelenggarakan tugas-tugas yang telah disebutkan, Kecamatan mempunyai fungsi:

a. Penyelenggaraan ketatausahaan Kecamatan;

b. Penyelenggaraan tugas-tugas pemerintahan umum Kecamatan;

c. Pembinaan pemerintahan desa dan kelurahan;

d. Penyelenggaraan ketentraman dan ketertiban umum;

e. Penyelenggaraan perekonomian;

f. Pengkoordinasian penyelenggaraan sosial kemasyarakatan dan kesejahteraan rakyat;

g. Penyelenggaraan pembangunan;

h. Pengkoordinasian perangkat daerah dalam wilayah kerja kecamatan dan

i. Pelaksanaan upaya pemberdayaan, menumbuhkan prakasa, kreativitas dan meningkatkan partisipasi masyarakat.

Jumlah pegawai Kecamatan Cisarua adalah 35 orang ditambah dengan berdasarkan kuantoitas dan kualitas keadaan Aapartur di Kecamatan Cisarua adalah sebagai berikut:

a. Berdasarkan status kepegawaian:

- Pegawai Negeri Sipil : 31 orang

- Tenaga Kontrak : 1 orang

- Sukarelawan : 3 orang

b. Berdasarkan tingkat pendidikan terakhir:

- $\mathrm{S} 2$

- $\mathrm{S} 1$

: 4 orang

- D4

: 7 orang

- D3

: 1 orang

- SMA/Sederajat

: 1 orang

- SMP/Sederajat

: 19 orang

: 1 orang

c. Berdasarkan eselonering/struktur jabatan:

- Eselon III/a : 1 orang

- Eselon III/b : 1 orang

- Eselon IV/a : 5 orang $\begin{array}{lll}\text { - } & \text { Eselon IV/b } & : 3 \text { orang } \\ \text { - } & \text { Staf/Pelaksana } & : 23 \text { orang } \\ \text { - } & \text { Sekretaris Desa } & : 4 \text { orang }\end{array}$

\section{KESIMPULAN DAN IMPLIKASI}

Berdasarkan hasil pembahasan yang telah dikemukakan dan dilakukan analisa, bahwa :

1. Implementasi Kebijakan Tata Ruang di Kawasan Puncak Kecamatan Cisarua masih tergolong belum begitu baik, hal ini disebabkan karena dalam pelaksanaan, unsur-unsur seperti komunikasi perihal sosialisasi teripinci tidak ada, sumber daya meliputi informasi, sumber daya manusia, wewenang relatif rendah serta sikap para pelaksana dan struktur birokrasi yang belum bersinergi sepenuhnya.

2. Sumber Daya, khususnya sumber daya manusia yang masih minim dalam pengawasan dimana seksi keamanan dan ketertiban memiliki 3 orang personil, sehingga dalam pelaksanaan pengawasan tata ruang belum memadai meningat wilayah Kecamatan Cisarua cukup luas.

3. Permasalahan yang muncul dalam kasus Tata Ruang tidak hanya pada bangunan liar, masalah lain muncul seperti pedagang kaki lima serta kecamatan Cisarua yang sebagian wilayahnya adalah wilayah konservasi, tetapi juga banyaknya potensi pariwisata menyebabkan penggunaan lahan menyempit.

4. Pembagian kewenangan berdasarkan jenjang kekuasaan dalam implementasi kebijakan, dalam hal ini dinas tata ruang amat berperan namun kurang melibatkan pelaksanan teknis yaitu pemerintah desa dan kecamatan

\section{DAFTAR PUSTAKA}

Anonim. (2009) Buku Panduan Penulisan Skripsi. Fakultas Ilmu Sosial, Ilmu Politik dan Ilmu Komunikasi Universitas Djuanda. Bogor.

Agustino, Leo. (2008) Dasar-dasar

Kebijakan Publik. Alfabeta. Bandung. 
Arikunto, Suharsimi. (2002) Prosedur Penelitian Edisi Revisi $V$. Rineka Cipta. Jakarta.

Djakapermana, Ruchyat Deni. (2010) Pengembangan Wilayah. IPB Press. Bogor.

Direktorat Jenderal Penataan Ruang. (2007)

Bahan Tayangan Materi Sosialisasi Undang-Undang Nomor 26 Tahun 2007 Tentang Penataan Ruang. Departemen Pekerjaan Umum. Jakarta.

Dunn, William N. (2003) Pengantar Analisis Kebijakan Publik; Edisi Kedua.

Yogyakarta.

Gadjah Mada University Press,

Fermana, Surya. (2009) Kebijakan Publik Sebuah Tinjauan Filosofis. Ar-Ruzz Media. Jogjakarta.

Hidayat, L Misbah. (2007) Reformasi Administrasi. Gramedia Pustaka Utama. Jakarta

Kumorotomo, Wahyudi. (2003) Etka Administrasi Negara. Rajawali Press. Jakarta

Moleong, Lexy J. (2001) Metodologi Penelitian Kualitatif. Remaja Rosda Karya. Bandung.

Narbuko, Cholid dan Abu Achmadi. (2004) Metodologi Penelitian. Bumi Aksara. Jakarta.

Saraswati, Sylvia. (2009) Cara Mudah Menyusun Proposal, Skripsi, Tesis, Disertasi. Ar-Ruzz Media. Jogjakarta.

Subarsono, AG. (2009) Analisis Kebijakan Publik. Pustaka Pelajar. Yogyakarta.

Sugiyono. (2007) Metode Penelitian Aministrasi. Alfabeta. Bandung.
Wibawa, Samodra. (2011) Politik Perumusan Kebijakan Publik. Penerbit Graha Ilmu. Yogyakarta

Wasistiono, Sadu. (2003) Kapita Selekta Manajemen Pemerintahan Daerah. Fokus Media. Bandung.

\section{Sumber Dokumen:}

- Master Plan Dinas Kebudayaan dan Pariwisata Kabupaten Bogor 2009

- Rencana Strategis Kecamatan Cisarua 2009

- Data Monografi Kecamatan Cisarua 2010

- Lampiran III Perda Nomor 19 Tahun 2008 (Indikasi Program Pembangunan Kabupaten Bogor)

Sumber Undang-Undang dan Peraturan:

- Undang-Undang Nomor 26 Tahun 2007 Tentang Penataan Ruang

- Peraturan Presiden Nomor 54 Tahun 2008 Tentang Penataan Ruang Kawasan Jakarta, Bogor, Depok, Tangerang, Bekasi, Puncak, Cianjur

- Peraturan Daerah Kabupaten Bogor Nomor 19 Tahun 2008 Tentang Rencana Tata Ruang Wilayah Kabupaten Bogor Tahun 2005-2025

- Pedoman Operasional Pemanfatan Ruang Peraturan Bupati Nomor 83 Tahun 2009

Sumber Artikel:

Dinas Tata Ruang dan Pertanahan Kabupaten Bogor. (2009) Tata Ruang Kawasan Puncak Memprihatinkan. Majalah Inovasi Edisi Ke 3 Tahun Ke 1, 27.

\section{Sumber Internet:}

- http:// www.bappedakabbogor.go.id

- http:// lintascerita.co.cc/puncak-yangsemakin-kacau/2011,March 23/15:35

- http:// megapolitan.kompas.com/read/2 ...Se makin.Kacau/2010,February 20/13:53. 